\title{
ODP LEG 137, BOREHOLE FLUID CHEMISTRY IN HOLE 504B
}

Andrew J. Magenheim ${ }^{1}$, Greg Bayhurst ${ }^{2}$, Jeff C. Alt ${ }^{3}$, Joris M. Gieskes1

Abstract. Borehole fluid samples collected from Site 504B, during ODP Leg 137, provide the best opportunity to date to study water-rock interaction within the ocean crust. Chemical composition of the borehole fluids reveal the results of seawater-basalt interaction at elevated temperatures. The borehole fluids can be described as a two component mixture, consisting of a reacted fluid component and seawater which has convectively mixed into the borehole from the seafloor. Progressive trends in fluid chemistry with time suggest that the fluid-rock reactions have changed as the borehole has been drilled deeper into the hotter formation Based on data from this study and comparisons to fluid studies from past visits to Site 504B, indications are that these reactions are occurring within the borehole environment.

\section{Introduction}

The study of fluids from oceanic boreholes can supply information regarding the composition of basaltic formation fluids. This information is necessary to elucidate the elemental exchanges between ocean crust and seawater. Mottl and Gieskes [1990] have reviewed the progress of sampling oceanic boreholes, including discussions of potential contaminants and sampling difficulties. In general three important processes may affect the borehole fluid composition: 1) mixing of the borehole fluids with bottom seawater via convective exchange; 2 ) reaction of the fluids with the wall rocks or drilling debris left inside the borehole; and 3) diffusive and/or advective exchange with formation fluids.

Hole 504B is located on the southern flank of the Costa Rica Rift, and has been the subject of 5 DSDP and ODP drilling legs. The borehole was drilled to a total depth of 489 mbsf and cased to basement ( $274 \mathrm{mbsf}$ ) during DSDP Leg 69. Hole 504B was then drilled deeper during DSDP Legs $70(836$ mbsf), 83 (1350 mbsf), and ODP Legs 111 (1562 mbsf), and Leg 137 (1621 mbsf). Temperature logs of the open borehole have revealed downhole flow of bottom seawater into the upper 100 meters of basement ( $300-400 \mathrm{mbsf}$ ), due to hydrostatic underpressure [Becker et al., 1983 and 1985]. This underpressure was apparently subsiding through Leg 111 [Gable et al., 1989], but temperature logging operations during Leg 137 indicated renewed downhole flow [Leg 137 Shipboard Scientific Party, in press and Gable et al., this issue]. Below the inflow zone temperature profiles are apparently the result of the conductive geothermal gradient, with a bottom temperature of $160^{\circ} \mathrm{C}$ at 1560 mbsf measured during Leg 137 [Shipboard Scientific Party, in press]. However, Fischer and Becker [in press] point out that nonsteady state "transitional" convection may be important in the hydrostatically unstable Hole 504B.

Borehole fluids have been sampled from Site 504B during DSDP legs 70, 83, 92 and ODP Legs 111 and 137. At the end of operations for each site visit, the borehole was flushed with surface seawater to remove drilling mud and debris. Fluid sampling, during the successive expeditions, was conducted

1Scripps Institution of Oceanography

2Los Alamos National Laboratory

3University of Michigan

Copyright 1992 by the American Geophysical Union.

Paper number 91GL02948

0094-8534/92/9IGL-02948\$03.00 prior to any drilling operations to avoid disturbance of the borehole fluids. This procedure has been quite successfu] except for the case of sampling during Leg 92 when large quantities of drilling mud were recovered in fluid samples resulting from inadequate flushing at the end of operations during Leg 83.

Chemical analyses of the borehole fluids show large changes in fluid composition relative to seawater, including decreased magnesium, sodium, and potassium concentrations and increased calcium concentration [c.f. Mottl and Gieskes, 1990]. Such chemical trends strongly suggest fluid-basalt reaction. One significant question which has remained unanswered regards the origin of the basalt reacted component of the borehole fluids. The origin of the reacted fluid could be either from (1) reaction of fluids within the borehole with the wall rock, or (2) true formation fluid which has exchanged with the borehole fluids by advection or molecular diffusion through the formation [Mottl and Gieskes, 1990].

In addition to chemical reaction, the fact that the borehole is open at the seafloor allows mixing of bottom seawater down into the borehole. Downhole convective exchange with bottom water has been inferred from the tritium concentrations of Hole 504B borehole fluids determined during legs 83, 92, and 111 [Mottl et al., 1985 and Mottl and Gieskes, 1990]. Tritium (the product of atmospheric nuclear testing) provides an unambiguous tracer for surface seawater, as deep waters of the Pacific Ocean are essentially void of this isotope of hydrogen. Thus the surface water pumped into the borehole can be distinguished from bottom water. Tritium concentrations in Site 504B borehole fluids increase with depth. This indicates that the surface seawater is slowly exchanging with bottom seawater, but has not completely been replaced. At the begining of Leg 111, 1233 days after filling the hole with surface seawater at the end of Leg $92,31 \%$ of the original fluid remained at the bottom of the borehole based on tritium measurements [Mottl and Gieskes, 1990]. Thus the deepest borehole fluids at that time were composed of components that originate as $31 \%$ surface seawater and the remainer most likely bottom seawater.

Preliminary results from fluid samples taken during ODP Leg 137 (March 1991) are considered here in context of prior results. Large pieces of anhydrite crusts were recovered from the bottom of the borehole, apparently precipitated from the borehole fluids themselves. Examinations of the fluids, anhydrite crusts, and surfaces of the basaltic rubble (recovered from the bottom of hole 504B during cleaning operations) are used to support the possibility of the water-rock reactions within the borehole.

\section{Methods}

Shipboard fluid sampling and analytical methods are discussed in detail elsewhere (Shipboard Scientific Party, in press). Chloride was analyzed by potentiometry, magnesium and calcium by titration, and silica by colorimetry [Gieskes and Peretsman, 1986]. Potassium, sodium, and lithium were analyzed by flame atomic emission spectrometry and strontium by flame atomic absorption spectrometry. Sulfate concentrations were determined using a Dionex ion chromatograph.

Anhydrite crusts and pieces of basaltic rubble recovered from the first junk mill were examined by scanning electron microscopy (SEM) and energy dispersive $x$-ray analysis (EDS). The anhydrite was dissolved in $2 \% \mathrm{HCl}$, and analyzed for Ca and Sr. 
Sulfur isotope analysis was performed on selected fluid samples, and the anhydrite crusts from the bottom of hole $504 \mathrm{~B}$. Data are presented as $834 \mathrm{~S}$ relative to Canyon Diablo Troilite (CDT), and errors are 0.4 per mil based on replicates of standards.

\section{Results}

Profiles of $\mathrm{Cl}, \mathrm{Mg}, \mathrm{Ca}, \mathrm{SO}_{4}, 834 \mathrm{SO}_{4}, \mathrm{Si}, \mathrm{Na}, \mathrm{K}$, and $\mathrm{Sr}$ are shown in Figure 1. The surface seawater $(S)$ and bottom seawater (B) values are given for reference. Major elements reflect bottom seawater composition present to at least 350 mbsf, supporting the observation of renewed downhole flow into the upper basement inferred from the temperature profiles [Gable et al., this issue]. Calcium, $\mathrm{Si}$, and $\mathrm{Cl}$ increase in concentration with depth while $\mathrm{Na}, \mathrm{Mg}, \mathrm{SO}_{4}, \delta 34 \mathrm{SO}_{4}$, and $\mathrm{K}$ decrease with depth.

Some data points, particularly samples from 1400 and 1550 mbsf, show deviation from the general downhole trends. These anomalies are the likely result of sampling artifacts. We believe these to be the result of disturbances to the water column created during prior sampling runs, resulting in the mixing of fluids from shallower depths in the borehole.

Element versus $\mathrm{Mg}$ mixing diagrams are provided in Figure 2. This format for data presentation provides a basis for establishing conservative mixing, and directions of relative chemical changes. The data for all elements fall along straight lines (with the exception of silica) suggesting conservative mixing of two components. The lines intersect near bottom seawater composition revealing bottom seawater as one "endmember" of the mixture. Silica data for the lowest $\mathrm{Mg}$ (largest component of reacted fluid) samples fall below the mixing lines suggesting polymerization or precipitation of a phase containing silica, either in the borehole or upon cooling during recovery of the samples. Two conclusions can be made from the excellent linearity of the elemental trends (Figure 2); 1) Samples that fall off the general downhole trends in Figure 1 are most likely the result of borehole disturbances created
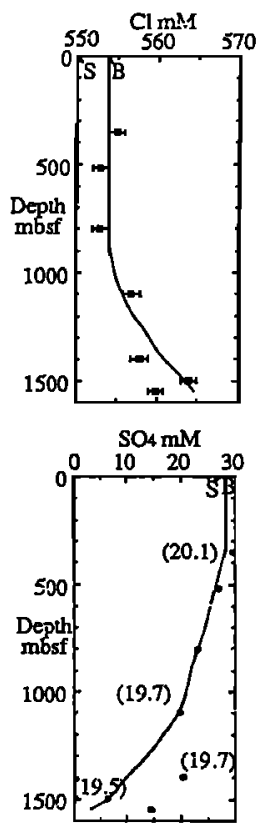

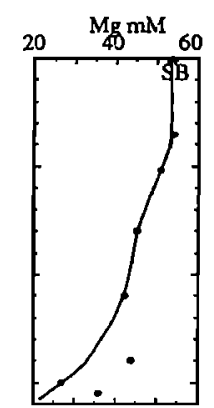

$\mathrm{Na} \mathrm{mM}$
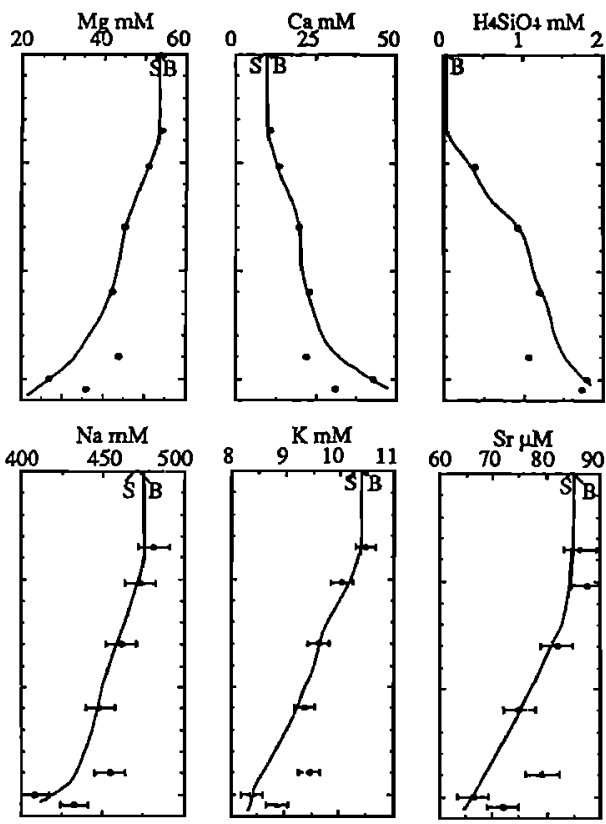

Fig. 1. Elemental borehole fluid profiles for Hole 504B, Leg 137. Error bars $(2 \sigma)$ are supplied. Sulfur isotopic values expressed as $\delta 34 \mathrm{SO}_{4}$ are given for selected values in parentheses on the $\mathrm{SO}_{4}$ profile. Values for oceanic surface water (S) and bottom water (B) are given for comparison.
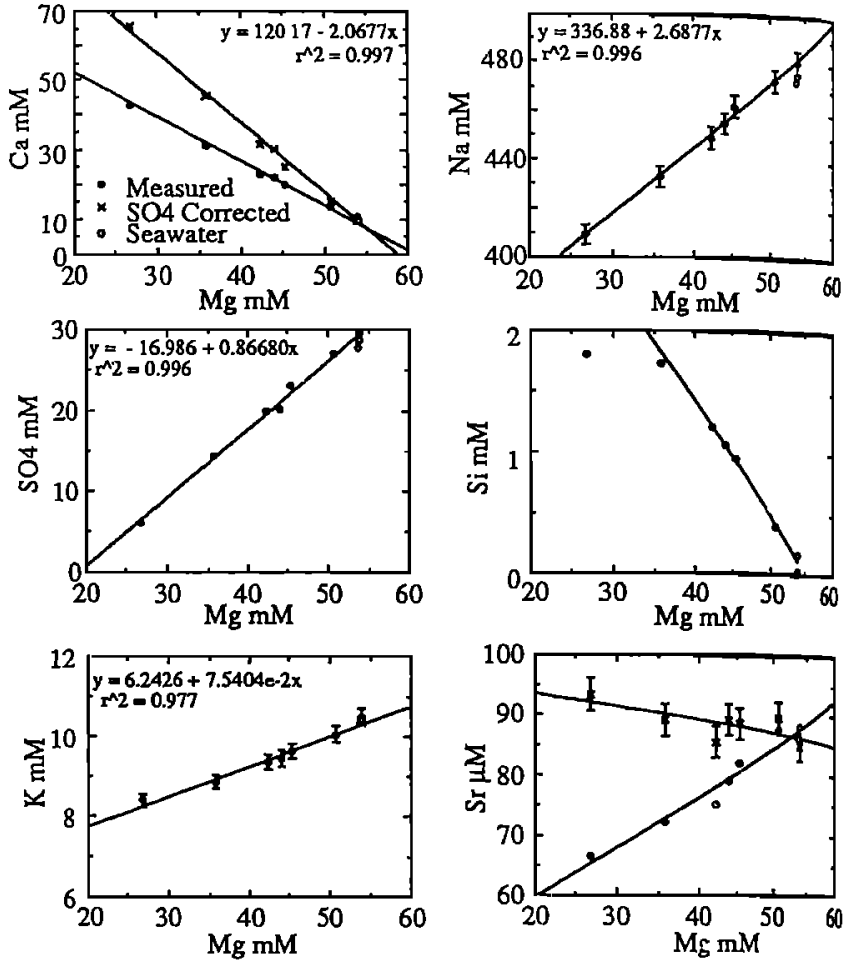

Fig. 2. Elemental mixing diagrams expressed versus $\mathrm{Mg}$. Open symbols are oceanic seawater. Crosses for $\mathrm{Ca}$ and $\mathrm{Sr}$ are the concentrations of these species corrected for the precipitation of anhydrite (see text).

during the sampling process, and 2) convective mixing of borehole fluids with bottom seawater must occur.

The recovery of large anhydrite crusts during initial fishing operations of Leg 137, confirmed by shipboard XRD [Shipboard Scientific Party, in press], suggests that this mineral is precipitated within the borehole environment. Sulfur isotope analyses of dissolved $\mathrm{SO}_{4}$ (Figure 1) provides further support for in situ anhydrite precipitation. The sample from 350 mbsf has a $834 \mathrm{SO}_{4}$ approximately equal to modem seawater $\left(\delta^{34} \mathrm{SO}_{4}=+20\right.$ per mil) consistent with the interpretation that bottom seawater has penetrated to this depth. Fluid samples from deeper are depleted in ${ }^{34} \mathrm{~S}$ to a value of +19.5 per mil at $1500 \mathrm{mbsf}$ and the $\delta 34 \mathrm{~S}$ of the anhydrite crusts gives a value of +21.4 per mil. These results are consistent with a slight positive fractionation of sulfur during anhydrite precipitation [Holser and Kaplan, 1966]. XRD analysis of suspended solids, collected from the Leg 137 water samples, revealed the major peaks of anhydrite, suggesting precipitation within the water column [Shipboard Scientific Party, in press]. Suspended anhydrite was also observed in the Leg 92 fluid samples [Gieskes et al., 1986]. However, the extent to which this observation was caused by the large quantity of drilling mud left in borehole, as a result of inefficient flushing at the end of Leg 83, left conclusions somewhat ambiguous.

Further indication that anhydrite precipitation is expected to occur in the moderate temperature borehole waters (maximum temperature $=160^{\circ} \mathrm{C}$ ) has been derived from experimental investigations. Precipitation of anhydrite has been observed to occur between $150^{\circ} \mathrm{C}$ and $200^{\circ} \mathrm{C}$ upon heating seawater [Bischoff and Seyfried, 1978], and in experimental seawaterrock reactions at temperatures as low as $150^{\circ} \mathrm{C}$ [Seyfried and Bischoff, 1979].

The increase in $\mathrm{Ca}$ due to fluid-rock inter-action is greater than measured, as precipitation of anhydrite will decrease the observed $\mathrm{Ca}$ concentration. For this reason the composition of 
the anhydrite was investigated to determine the effect of the precipitation of this mineral on other elemental concentrations, particularly Sr. High values of $\mathrm{Sr}$ were measured in the anhydrite crusts with $\mathrm{Sr} / \mathrm{Ca}$ molar ratios of $1.20 \times 10^{-3} \mathrm{Sr} / \mathrm{Ca}$. Correction of the measured $\mathrm{Ca}$ and $\mathrm{Sr}$ concentrations can be made for the decrease in these elements due to anhydrite precipitation based on the change in $\mathrm{SO}_{4}$ from seawater concentration. The corrected $\mathrm{Ca}$ and $\mathrm{Sr}$ concentrations reveal the effects of water-rock reaction in absence of this removal (Figure 2). These results show that the ratio of $\mathrm{Ca}$ enrichment to $\mathrm{Mg}$ depletion is 2:1 in the absence of anhydrite precipitation. The $\mathrm{Sr}$ mixing diagram demonstrates that $\mathrm{Sr}$ is actually enriched in the borehole fluids in the absence of anhydrite precipitation, and hence must be leached from the rock and subsequently removed in anhydrite. While $\mathrm{Sr}$ isotopes have yet to be analyzed for the Leg 137 samples, $87 \mathrm{Sr} / 86 \mathrm{Sr}$ has been oberved to decrease in the borehole fluids [Mottl and Gieskes, 1990]

SEM investigations of anhydrite crusts and surfaces of the basaltic rubble recovered from the bottom of Hole 504B provide some clues to reactions occurring within the borehole. Figure 3a shows surface coatings on basaltic rubble. These $100-200 \mu \mathrm{m}$ thick coatings are $\mathrm{Mg}$ rich silicates (predominantly smectite/chlorite). These are apparently products of seawater-basalt reaction at $5160^{\circ} \mathrm{C}$ in the bottom of Hole $504 \mathrm{~B}$ that have apparently grown while the rubble resided at the bottom of the borehole for the 1633 days since Leg 111. The coatings on the rubble support the hypothesis that reactions between fluids and rocks within the borehole do occur, albeit in this case the reactants are pieces of basalt rubble from the hole bottom rather than wall rocks. A similar $\mathrm{Mg}$ rich alteration phase is also present in the anhydrite crusts (Figure 3b) at levels of 4-6 weight percent (based on anhydrite dissolution). While these silicates cannot conclusively be shown to be authigenic precipitates from the borehole fluids, the interbedded nature of the silicate and anhydrite suggests coprecipitation of the two phases.

\section{Discussion}

Mottl and Gieskes [1990] have reviewed the geochemistry of all past fluid samples taken from Hole 504B prior to Leg 137. The samples were taken after allowing the borehole to remain undisturbed for periods ranging from 37 days to 1633 days, and bottom hole temperatures increasing from $80^{\circ} \mathrm{C}$ during Leg 70 to over $160^{\circ} \mathrm{C}$ at the beginning of Leg 137 [Gable et al., 1989]. Mottl and Gieskes [1990] do not comment on the differences in the observed mixing lines between legs, rather the general trends are extrapolated to zero $\mathrm{Mg}$ to establish a "borehole fluid endmember" from the combined data. It is, however, likely that the extent and nature of the reactions between basalt and seawater could change given the variability in borehole temperatures and equilibration
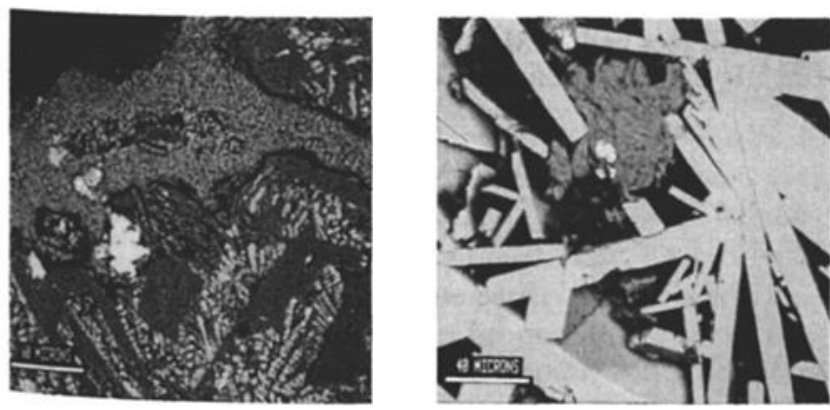

Fig. 3. SEM images of a) smectite/chlorite coating a piece of basaltic rubble, and b) anhydrite crust interbedded with $\mathrm{Mg}$ silicate. time. Figure 4 presents mixing lines of $\mathrm{Ca}$ (corrected for anhydrite precip-itation, see discussion above), $\mathrm{Na}$, and $\mathrm{K}$ versus $\mathrm{Mg}$ for samples from Legs 70 (Mg-Ca only), 83, 92, 111 and 137. While each Leg defines a discrete mixing line, it is apparent that systematic differences occur when comparing results from legs 70 through 137 . Ca concentrations corrected for anhydrite precipitation reveal a monotonic increase in $\mathrm{Ca}$ released relative to $\mathrm{Mg}$ removed from Leg 70 through 137 . Alternately, $\mathrm{Na}$ uptake relative to $\mathrm{Mg}$ uptake appears to increase over the same interval. Potassium uptake is waning from Leg 83 through Leg 137 as bottom hole temperature has increased. The combined evidence, therefore, argues in favor of a progressive evolution of the reacted fluid, as the bottom hole temperature increased.

The observation of $\mathrm{Na}$ uptake at temperatures of $5160^{\circ} \mathrm{C}$ is interesting in that it is not observed experimentally. During the $150^{\circ} \mathrm{C}$ water/rock experiments of Seyfried and Bischoff [1979] no significant change in $\mathrm{Na}$ concentration was observed. Mottl [1983] suggests that $\mathrm{Na}$ can be taken up into secondary albite and zeolites, but leaching $\mathrm{Na}$ from basalt is favored at high water/rock ratios. However, $\mathrm{Na}$ uptake has been noted in many low temperature formations where $\mathrm{Mg}$ is depleted in the interstitial fluids, apparently resulting from the exhange of $\mathrm{Na}$ for $\mathrm{Ca}$ in the underlying basement [e.g. McDuff, 1981]. We believe that the apparent discrepancy between experimental results and observations is an as yet unresolved problem, which deserves additonal study.

One significant problem regarding reaction of the fluids with the wall rocks remains. Oxygen isotopic analyses from past legs have revealed no significant change from seawater values. Mottl and Gieskes [1990] propose that this may be the result of high water/rock ratios. This is in apparent disagreement with the large observed changes in major elements from the fluid chemistry suggesting reaction at low water/rock ratios. For a borehole of $30 \mathrm{~cm}$ diameter and assuming a density of rock of $2.5 \mathrm{~g} / \mathrm{cm}^{3}$, reaction of $0.5 \mathrm{~mm}$ of rock would yield a water/rock ratio of near 100 . A water rock ratio this high could justify the absence of an oxygen isotope shift in the fluids. However, the observed fluid chemistry would require that the altered rock would have to gain $\sim 16 \% \mathrm{Na}, 6.1$ $\% \mathrm{Mg}$, and lose $20 \% \mathrm{Ca}$. Reaction to this extent seems unlikely, and decreasing the water/rock ratio to 10 would require only gains of $\sim 1.6 \%$ in $\mathrm{Na}$ and $0.15 \% \mathrm{Mg}$ and loss of $0.5 \% \mathrm{Ca}$. However, reaction at these temperatures and water rock ratios of 10 would require a shift in 8180 . One possibility is that reaction occurs primarily in the rubble and debris left at the bottom of the borehole, thus at a much lower W/R than would be present in the open borehole. Assuming $\mathrm{Mg}=0 \mathrm{mM}$ in this reaction zone the sample RFT-3 from Leg 111 [Mottl and Gieskes, 1990] represents only a $45 \%$ mixture of this component and seawater. If $\delta 180$ in the reaction zone is -1.5 per mil, the measured $\delta 180$ value of -0.6 is the result of this mixture. Thus, reaction in the rubble at the base of the hole could account for the relatively small contribution of 180 to the borehole fluids and the apparently low water/rock ratio that produces the observed fluid chemistry.

\section{Summary}

Fluid samples from borehole logging of Hole 504B during ODP Leg 137 reveal the effects of water-rock reaction at elevated temperatures. Fluids are enriched in $\mathrm{Ca}$ and $\mathrm{Si}$, and depleted in $\mathrm{Na}, \mathrm{Mg}$ and $\mathrm{K}$ relative to seawater. Fluids are a mixture between a reacted fluid component and bottom seawater. Anhydrite precipitation is actively occurring in the borehole as excess $\mathrm{Ca}$ is supplied from water-rock reaction and $\mathrm{SO}_{4}$ is supplied via convective mixing with bottom water. Recovery and examination of silicate reaction products in anhydrite crusts and on basalt rubble from the bottom of Hole 504B supports the conclusion that reaction of borehole fluids at high temperatures appears to occur at the borehole bottom. 

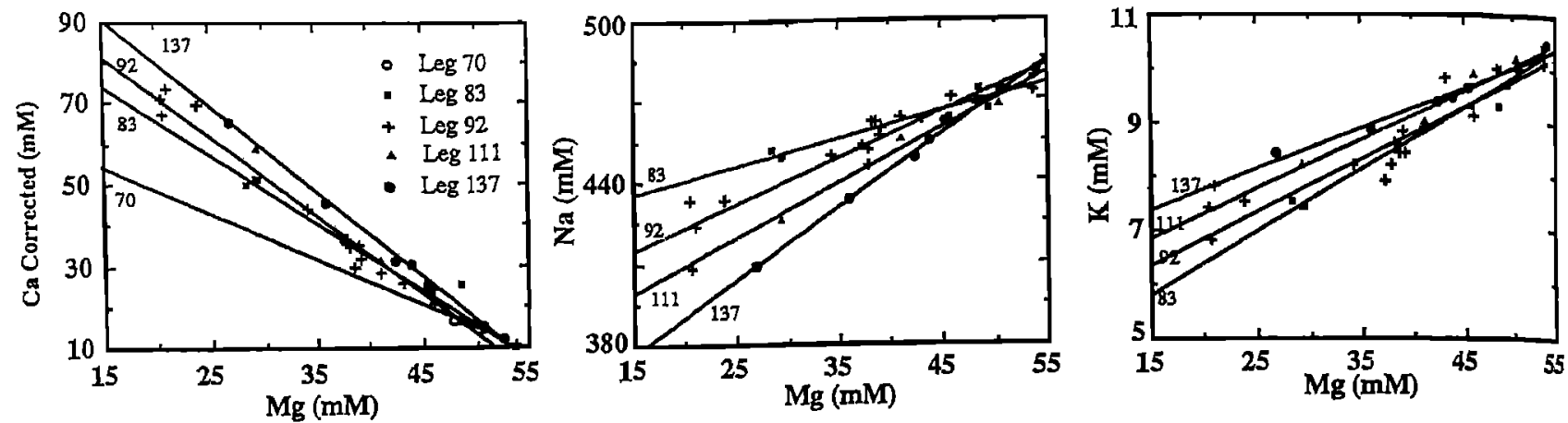

Fig. 4. Elemental mixing diagrams from fluid samples taken during each of the DSDP/ODP Legs. Lines are drawn to represent trend for individual legs. Ca values are corrected for anhydrite precipitation (see text). Data from past legs are from Mottl and Gieskes, 1990, Gieskes et al., 1986, and Mottl et al., 1985.

Comparison of mixing trends of previous borehole fluid samples taken from $504 \mathrm{~B}$ reveals progressively increased $\mathrm{Na}$ uptake and $\mathrm{Ca}$ release relative to $\mathrm{Mg}$ uptake as bottom hole temperatures increase. This apparently results from changing water rock interaction as the bottom hole temperatures are elevated concurrent with deepening of the borehole. Recovery of rubble coated with reaction products from the bottom of hole 504B provides evidence for these reactions. The chemical and physical evidence presented here point towards water-rock exchange taking place in the rubble accumulated at the bottom of the borehole.

Aknowledgements. The authors are indebted to the thoughtful reviews by Dr. Karen VonDamm and Dr. Russ McDuff who helped to improve this manuscript. This research is associated with the Ocean Drilling Program and supported by the National Science Foundation and the Joint Oceanographic Institutions, Inc.

\section{References}

Becker, K., Langseth, M.G., and Von Herzen, R.P, Deep crustal geothermal measurements, Hole 504B, Deep Sea Drilling Project Legs 69 and 70 . In Cann, J.R. Langseth, M.G. et al., Init. Repts. DSDP 69, U.S. Govt. Printing Press (Wash. D.C): 223-236, 1983.

Becker, K., Langseth, M.G., Von Herzen, R.P, Anderson, R.N. and Hobart, M.A., Deep crustal geothermal measurements, Hole 504B, Deep Sea Drilling Project Legs 69, 70, and 92. In Andersen, R.N. Honnorez, J. et al., Init. Repts. DSDP 83, U.S. Govt. Printing Press (Wash. D.C): 405-418, 1985.

Bischoff, J.L., and Seyfried, W.E., Hydrothermal chemistry of seawater from $25^{\circ} \mathrm{C}$ to $350^{\circ} \mathrm{C}$. Am. J. Sci., 278: 838$860,1978$.

Fischer, A.T., and Becker, K., in press. The reduction of measured heat flow with depth in DSDP Hole 504B: evidence for convection of borehole fluids. Sci. Drill., in press.

Gieskes, J.M. and Peretsman, G., Water chemistry aboard Joides Resolution. Ocean Drilling Program, Tech. Note \#5, 46 pp, 1986.

Gieskes, J.M., Kastner, M., Erzinger, J., and Boulegue, J., Geochemical studies in Hole 504B, Leg 92. In Leinen,
M. and Rea, D.K., et al., Init Repts. DSDP, 92: U.S. Govt. Printing Office (Wash. D.C.), 547-562, 1986.

Gable, R., Morin, R.H., and Becker, K., Geothermal state of Hole 504B: ODP Leg 111 overview. In Becker, $\mathrm{K}$. Sakai, H., et al., Proc. ODP, Sci. Res., 111: College Station, TX (Ocean Drilling Program), 87-96, 1989.

Holser, W.T. and Kaplan, I.R., Isotope geochemistry of sedimentary sulfates. Chem. Geo., 1: 93-135, 1966.

McDuff, R.E., Major cation gradients in DSDP interstitla waters: the role of diffusive exchange between seawater and the upper ocean crust. Geochim. Cosmochim Acto, 45: 1705-17.13, 1981.

Mottl, M.J., Metabasalts, axial hot springs, and the structure of hydrothermal systems at mid-ocean ridges. Geo Soc Amer. Bull., 94: 161-180, 1983.

Mottl, M.J., and Gieskes, J.M., Chemistry of waters sampled from oceanic basement boreholes, 1979-1988. $J G R$, 95(B6): 9327-9342, 1990.

Mottl, M.J., Druffel, E.M., Hart, S.M., Lawrence, J.R., and Caltzman, E., Chemistry of hot water sampled in Hole 504B, DSDP Leg 83. In Anderson, R.N., Honnorez, J., et al., Init. Repts. DSDP, 83: U.S. Govt. Printing Office (Wash. D.C.), 315-330, 1985.

Shipboard Scientific Party,Proc. ODP, Init. Repts. Pt. A), 137:College Station, TX (Ocean Drilling Program), in press.

Shipboard Scientific Party, Proc. ODP, Init. Repts. Pt. A), 111:College Station, TX (Ocean Drilling Program), 1988.

Seyfried, W.E. and Bischoff, J.L., Low temperature basalt alteration by seawater: an experimental study at $70^{\circ} \mathrm{C}$ and $150^{\circ} \mathrm{C}$. Geochim. Cosmochim. Acta, 43:1937-1947, 1979.

J. Alt, Dept. of Goelogical Science, Univ. of Michigan, Ann Arbor MI 48109-1063.

G. Bayhurst, Los Alamos National Lab, Box 1663, Los Alamos NM 87545

J. Gieskes and A. Magenheim, Marine Research Division 0215-F, SIO, La Jolla CA 92037-0215.

(Received: August 29, 1991

Revised: November 5, 1991

Accepted: Novemver 5, 1991) 